\title{
Membangun Self-Confidence Siswa melalui Pembelajaran Matematika
}

\author{
Meri Andayani ${ }^{*}$, Zubaidah Amir ${ }^{1}$ \\ ${ }^{1}$ Universitas Islam Negeri Sultan Syarif Kasim Riau, Jalan H.R. Subrantas No. 155 Km. 15, \\ Simpang Baru Panam, Pekanbaru, 28293, Indonesia \\ * Corresponding Author Email:meriandayani1302@gmail.com
}

\begin{abstract}
Abstrak
Self confidence adalah aspek kepribadian yang penting pada diri seseorang. Self confidence merupakan suatu sikap atau perasaan yakin atas kemampuan diri sendiri sehingga orang yang bersangkutan tidak terlalu cemas dalam tindakan-tindakannya, dapat merasa bebas untuk melakukan hal-hal yang disukainya, bertanggung jawab atas tindakannya, hangat dan sopan dalam berinteraksi dengan orang lain, memiliki dorongan untuk berprestasi serta mengenal kelebihan dan kekurangan dirinya. Pembelajaran matematika salah satu pembelajaran yang dapat membangkit kan sikap self confidence siswa, sehingga dapat meningkatkan prestasi dan hasil belajar di sekolah.
\end{abstract}

Kata kunci:Self confidence, pembelajaran matematika.

\section{Abstract}

Self-confidence is an important aspect of personality in a person. Self confidence is an attitude or feeling of confidence in one's own abilities so that the person concerned is not too anxious in his actions, can feel free to do things he likes, and is responsible for his actions, warm and polite in interacting with others, have an urge to excel and recognize their strengths and weaknesses. Mathematics learning is one of learning that can generate students' self confidence attitudes, so that it can improve achievement and learning outcomes in school.

Keywords: Self confidence, mathematics learning.

\section{PENDAHULUAN}

Pendidikan adalah usaha sadar dan terencana untuk mewujudkan suasana belajar dan proses pembelajaran agar siswa secara aktif mengembangkan potensi dirinya untuk memiliki kekuatan spiritual keagamaan, pengendalian diri, kepribadian, kecerdasan, akhlak mulia, serta ketrampilan yang diperlukan dirinya, masyarakat, bangsa dan negara. (Ramayulis, 2015). Pendidikan matematika menjadi salah satu yang dapat menciptakan pembelajaran yang aktif untuk mengembangkan potensi diri siswa. Pembelajaran matematika harus mengalami perubahan dalam konteks perbaikan mutu pendidikan sehingga dapat meningkatkan hasil pembelajaran yang optimal dan maksimal. Oleh karena itu, upaya terus dilakukan untuk terwujudnya suatu pembelajaran yang inovatif sesuai dengan perkembangan zaman dan teknologi.

Matematika adalah salah satu pelajaran yang diajarkan di sekolah yang bermanfaat bagi kehidupan sehari-hari karena berbagai masalah kehidupan sehari-hari dapat dimodelkan dalam matematika untuk kemudian dicari solusinya berdasarkan kaidah-kaidah yang terdapat dalam matematika. Matematika merupakan suatu kegiatan yang kompleks, melibatkan berbagai unsur seperti guru, siswa, matematika dan karakteristiknya, dan situasi belajar yang berlangsung (Sumarmo, 2017). Sebagai generasi penerus bangsa, sikap kepercayaan diri sangat penting ditanamkan pada diri seorang siswa agar ia tumbuh menjadi sosok yang mampu mengembangkan potensi dirinya. Sikap ini harus diterapkan dalam pembelajaran matematika, terkadang mereka kurang menghargai diri sendiri dan hanya melihat 
kelemahan mereka sehingga menganggap diri mereka tidak layak, tidak memadai atau dengan kata lain kurang serius atau percaya diri. Kepercayaan diri atau self confidence merupakan salah satu syarat yang esensial bagi individu atau siswa untuk mengembangkan aktivitas dan kreativitas sebagai upaya dalam mencapai prestasi belajar dan hasil belajar yang optimal.

Berdasarkan beberapa penelitian yang telah dilakukan sebelumnya, beberapa penelitian telah membahas mengenai Self confidence (Firdaus, 2018; Martyanti, 2016; Mostajaboldavati, Khansanami, \& Khansanami, 2017; Warda, Mashuri, \& Amidi, 2017; Yusmanto \& Herman, 2015). Namun, belum adanya penelitian yang mencoba membangun Self confidence melalui pembelajaran matematika. Keterbaruan penelitian ini terletak pada analisis mengenai peningkatan Self confidence melalui pembelajaran matematika

\section{METODE PENELITIAN}

Jenis penelitian yang digunakan adalah model penelitian kualitatif dengan kajian literatur. Penelitian kualitatif bertujuan memperoleh gambaran seutuhnya mengenai suatu hal menurut pandangan manusia yang diteliti. Penelitian kualitatif berhubungan dengan ide, persepsi, pendapat, atau kepercayaan orang yang diteliti, kesemuanya tidak dapat diukur dengan angka

\section{HASIL DAN PEMBAHASAN}

\section{Pembelajaran Matematika}

Matematika merupakan salah satu bidang studi yang ada pada semua jenjang pendidikan, mulai dari tingkat sekolah dasar hingga ketingkat perguruan tinggi.Pada umumnya peristiwa-peristiwa yang kita alami selama ini setiap harinya banyak yang berhubungan dengan matematika. Misalkan mengukur luas tanah, mengukur tinggi badan, transaksi jual beli di pasar, dan lain-lain memerlukan perhitungan matematika. Menurut Amir Matematika sekolah diberikan bertujuan untuk membantu siswa mempersiapkan diri agar sanggup menghadapi perubahan keadaan di dalam kehidupan dan di dunia yang selalu berkembang, melalui latihan bertindak atas dasar pemikiran secara logis, rasional dan kritis(Amir, 2015)

Menurut Vandini, hal ini disebabkan ruang lingkup matematika itu sendiri bersifat abstrak (tidak konkrit)(Vandini, 2015). Untuk dapat lebih memahami bagaimana hakikat matematika, kita dapat melihat dan memperhatikan pengertian istilah matematika dan beberapa definisi yang telah dijelaskan oleh para ahli. Pembelajaran matematika adalah proses interaksi antara guru dan siswa yang melibatkan pola berpikir siswa dan berbuat untuk mengerjakan matematika dan menghubungkan ide abstrak matematika dengan kehidupannya.

Sumarmo mengemukakan bahwa pembelajaran matematika merupakan suatu kegiatan yang kompleks, melibatkan berbagai unsur seperti guru, siswa, matematika dan karakteristiknya, dan situasi belajar yang berlangsung.(Sumarmo, 2017) Oleh karena itulah pembelajaran tidak dapat disederhanakan menjadi suatu resep untuk membantu siswa belajar. Paling sedikit terdapat dua hal yang menjadi alasan bahwa pembelajaran tidak dapat dirumuskan dalam bentuk resep. Pertama, pembelajaran melibatkan pengetahuan tentang: topik matematika yang akan diajarkan, perbedaan siswa, cara siswa belajar, lingkungan kelas, lembaga pendidikan dan masyarakat. Selain hal umum seperti di atas, guru juga harus mempertimbangkan hal-hal khusus misalnya: karakteristik topik yang akan diajarkan dan pedagogi mengajarkannya. Kedua, sebagai implikasi bahwa pembelajaran melibatkan berbagai domain, maka guru juga harus menetapkan: cara mengajukan dan 
Desimal, 2 (2), 2019 - 149

Meri Andayani, Zubaidah Amir

merespons pertanyaan, cara menyajikan idea matematika secara tepat, berapa lama diskusi perlu dilaksanakan, jenis dan kedalaman tugas matematika, dan keseimbangan antara tujuan dan pertimbangan.

Kerja matematika pada umumnya di alam ide, oleh sebab itu objek kerja matematika bersifat abstrak. Menurut Maarif, Objek abstrak matematika meliputi: Objek langsung, yaitu fakta yang merupakan angka atau lambang bilangan, keterampilan yaitu kemampuan memberikan jawaban yang benar dan cepat, konsep adalah ide ekstrak yang memungkinkan kita mengelompokkan benda-benda (objek) ke dalam contoh, aturan adalah objek yang paling abstrak. Sedangkan objek tidak langsung, meliputi: Kemampuan menyelidiki, kemampuan memecahkan masalah, kemampuan belajar dan bekerja mandiri, bersikap positif terhadap matematika. (Maarif, 2015)

Matematika disebut juga ilmu symbol. Ide-ide matematika yang bersifat abstrak dituangkan dalam bentuk symbol yang kosong dari makna, simbol-simbol dalam matematika pada umumnya masih "kosong dari arti" sehingga dapat diberikan arti kepada simbol-simbol itu sendiri sesuai dengan lingkup dan semestanya. Keberadaan simbol ini memberi peluang yang besar kepada matematika untuk digunakan dalam berbagai ilmu dan kehidupan nyata. Seperti contoh symbol 1, 2, 3, 4, dan seterusnya tidak memiliki makna apaapa, akan tetapi ide bilangan 1, 2, 3, dan seterusnya ada di alam ide seperti banyakanya benda yang dimiliki oleh seseorang berjumlah 2 dan sebagainya. Suatu kebenaran pangkal matematika disebut definisi ataupun postulat yang disepakati secara umum dan berlaku umum. Kebenaran-kebenaran matematika ditentukan oleh kebenaran-kebenaran sebelumnya yang ditarik oleh sebuah kesimpulan secara deduktif aksiomatis.

\section{Self-Confidence}

Sebagai generasi penerus bangsa, sikap kepercayaan diri sangat penting ditanamkan pada diri seorang siswa agar ia tumbuh menjadi sosok yang mampu mengembangkan potensi yang ada pada dirinya.Menurut Syam,A dan Amri , Percaya diri atau self confidence adalah aspek kepribadian yang penting pada diri seseorang. Tidak adanya kepercayaan diri pada seseorang maka akan banyak menimbulkan masalah pada diri seseorang tersebut. (Syam \& Amri, 2017) Kepercayaan diri merupakan atribut yang paling berharga pada diri seseorang dalam kehidupan bermasyarakat, karena dengan adanya kepercayaan diri, seseorang mampu mengaktualisasikan segala potensi yang ada di dalam dirinya. Sifat percaya diri ini juga dapat dipengaruhi oleh kemampuan dan keterampilan yang dimiliki. Siswa yang memiliki sifat percaya diri yang tinggi akan mudah berinteraksi dengan siswa lainnya, mampu mengeluarkan pendapat dan menghargai pendapat orang lain, mampu bertindak dan berpikir positif dalam pengambilan keputusan, sebaliknya siswa yang memiliki kepercayaan diri yang rendah akan sulit untuk berkomunikasi, berpendapat, dan akan merasa bahwa dirinya tidak dapat menyaingi siswa yang lain.

Vandini berpendapat bahwa kelebihan yang ada di dalam diri seseorang harus dikembangkan agar menjadi produktif dan berguna bagi orang lain. Kepercayaan diri merupakan dasar dari motivasi diri untuk berhasil. Agar termotivasi seseorang harus percaya diri. Seseorang yang mendapatkan ketenangan dan kepercayaan diri haruslah menginginkan dan termotivasi dirinya. Banyak orang yang mengalami kekurangan tetapi bangkit melampaui kekurangan sehingga benar benar mengalahkan kemalangan dengan mempunyai kepercayaan diri dan 
Desimal, 2 (2), 2019 - 150

Meri Andayani, Zubaidah Amir

motivasi untuk terus tumbuh.(Vandini, 2015)

Sumarmo mengemukakan bahwa kepercayaan diri (self-confidence) merupakan suatu sikap atau perasaan yakin atas kemampuan diri sendiri sehingga orang yang bersangkutan tidak terlalu cemas dalam tindakantindakannya, dapat merasa bebas untuk melakukan hal-hal yang disukainya, dan bertanggung jawab atas tindakannya, hangat dan sopan dalam berinteraksi dengan orang lain, memiliki dorongan untuk berprestasi serta mengenal kelebihan dan kekurangan dirinya. Kepercayaan diri merupakan suatu keyakinan dan sikap seseorang terhadap kemampuan pada dirinya sendiri dengan menerima secara apa adanya baik positif maupun negatif yang dibentuk dan dipelajari. Percaya diri adalah modal dasar seorang manusia dalam memenuhi berbagai kebutuhan sendiri. Seseorang mempunyai kebutuhan untuk kebebasan berpikir dan berperasaan sehungga seseorang yang mempunyai kebebasan berpikir dan berperasaan akan tumbuh menjadi manusia dengan rasa percaya diri. (Sumarmo, 2017)

Salah satu langkah pertama dalam membangun rasa percaya diri adalah memahami dan meyakini bahwa setiap manusia memilki kelebihan dan kelemahan masing-masing. Seperti yang diungkapkan Vandini rasa percaya diri tidak muncul begitu saja pada diri seseorang ada proses tertentu di dalam pribadinya sehingga terjadilah pembentukan rasa percaya diri.(Vandini, 2015) Rasa kepercayaan diri harus terus dilatih dan dikembangkan agar bisa bermanfaat dalam kehidupan. Terbentuknya rasa kepercayaan diri yang kuat terbentuk melalui proses perkembangan yang melahirkan kelebihan-kelebihan tertentu, pemahaman-pemahaman seseorang terhadap kelebihan-kelebihan yang dimilikinya dan melahirkan keyakinan yang kuat, pemahaman dan reaksi positif terhadap kelemahan-kelemahannya yang dimiliki, dan pengalaman di dalam menjalani berbagai aspek kehidupan dengan menggunakan segala kelebihan yang ada pada dirinya.

Aspek-aspek self confidence dikemukan oleh Sumarmo sebagai berikut.

a. Keyakinan akan kemampuan diri yaitu sikap positif seseorang tentang dirinya bahwa mengerti sungguh sungguh akan apa yang dilakukannya.

b. Optimis yaitu sikap positif seseorang yang selalu berpandangan baik dalam menghadapi segala hal tentang diri, harapan dan kemampuan.

c. Obyektif yaitu orang yang percaya diri memandang permasalahan atau segala sesuatu sesuai dengan kebenaran semestinya, bukan menurut kebenaran pribadi atau menurut dirinya sendiri.

d. Bertanggung jawab yaitu kesediaan seseorang untuk menanggung segala sesuatu yang telah menjadi konsekuensinya.

e. Rasional atau realistis yaitu analis terhadap suatu masalah, suatu hal, sesuatu kejadian dengan mengunakan pemikiran yang diterima oleh akal dan sesuai dengan kenyataan.(Sumarmo, 2017)

Terdapat beberapa cara yang ditempuh oleh guru untuk membangun karakter kepercayaan diri pada peserta didik yaitu:

a. Memberi pujian atas setiap pencapaian Sesederhana apapun yang dilakukan oleh peserta didik, namun jika itu bernilai kebaikan, guru harus memberikan apresiasi berupa pujian.

b. Mengajari peserta didik untuk bertanggung jawab Banyak hal yang dapat dilakukan oleh guru untuk menerapkan prinsip ini, seperti menugaskan peserta didik menjadi 
Desimal, 2 (2), 2019 - 151

Meri Andayani, Zubaidah Amir

pembawa acara atau pemimpin rapat di kelas.

c. Mengajari peserta didik bersikap ramah dan senang membantu Untuk mengajari peserta didik seperti itu guru harus selalu ramah terhadap siapapun sekaligus senantiasa tersenyum kepadanya.

d. Mengubah kesalahan menjadi bahan baku demi kemajuan Saat peserta didik melakukan suatu kesalahan, guru harus tetap fokus pada kemajuan yang telah dicapainya, bukan pada kesalahan ataupun kegagalan yang dialaminya.

Faktor-faktor yang mempengaruhi kepercayaan diri:

1. Faktor internal, meliputi:

a. Konsep diri Terbentuknya rasa kepercayaan diri pada seseorang diawali dengan perkembangan konsep diri yang diperoleh dari suatu pergaulan kelompok. Pergaulan kelompok memberikan dampak yang positif juga dampak negatif.

b. Harga diri Harga diri adalah penilaian yang dilakukan terhadap diri sendiri. Orang yang memiliki harga diri tinggi akan menilai dirinya secara rasional bagi dirinya serta mudah mengadakan hubungan dengan individu lain.

c. Kondisi fisik Perubahan kondisi fisik juga berpengaruh pada kepercayaan diri. Fisik yang sehat dapat membantu peserta didik dalam meningkatkan kepercyaan diri yang kuat. Sedangkan fisik yang kurang baik menyebabkan peserta didik lemah dalam mengembangkan kepercayaan diri.

d. Pengalaman hidup Kepercayaan diri diperoleh dari pengalaman yang mengecewakan karena dari pengalaman yang mengecewakan tersebut muncul rasa rendah diri sehingga nanti timbul kepercayaan diri yang kuat.

\section{Faktor eksternal}

a. Pendidikan Pendidikan mempengaruhi rasa kepercayaan diri seseorang. Tingkat pendidikan yang rendah akan cenderung di bawah kekuasaan yang lebih pandai. Sedangkan individu yang pendidikannya lebih tinggi cenderung mandiri dan tingkat kepercayaan dirinya tinggi.

b. Pekerjaan Bekerja dapat mengembangkan kreativitas dan rasa kepercayaan diri. Kepuasan dan rasa bangga didapat karena mampu mengembangkan diri.

c. Lingkungan dan pengalaman hidup Lingkungan disini adalah lingkungan keluarga dan masyarakat. Dukungan yang baik diterima dari lingkungan keluarga seperti anggota keluarga yang berinteraksi dengan baik akan memberi rasa nyaman dan percaya diri yang tinggi. Dalam lingkungan masyarakat semakin bisa memenuhi norma dan diterima masyarakat.

\section{Self-Confidence Dalam Pembelajaran Matematika}

Sifat percaya diri atau self confidence tidak hanya harus dimiliki oleh orang dewasa, tetapi anak-anak terutama seorang siswa juga memerlukannya dalam perkembangannya menjadi dewasa. Sifat percaya diri sulit dikatakan secara nyata, tetapi kemungkinan besar orang yang percaya diri akan bisa menerima dirinya sendiri, siap menerima tantangan dalam arti mau mencoba sesuatu yang baru walaupun ia sadar bahwa kemungkinan salah pasti ada. Matematika sebagai salah satu mata 
Desimal, 2 (2), 2019 - 152

Meri Andayani, Zubaidah Amir

pelajaran yang dianggap sulit oleh siswa dapat menjadi sarana untuk membangun kepercayaan diri siswa. Untuk itu guru sebagai orang yang paling berpengaruh dan terdekat hubungannya dengan siswa di sekolah harus memahami terlebih dahulu kesulitan, kelemahan dan hambatan siswa dalam membangun kepercayaan dirinya. Kepercayaan diri merupakan salah satu syarat yang esensial bagi individu atau siswa untuk mengembangkan aktivitas dan kreativitas sebagai upaya dalam mencapai prestasi belajar. Siswa yang memiliki self-confidence bisa sukses dalam belajar matematika.

Menurut Hannula, Maijala \& Pehkonen kepecayaan siswa pada matematika dan pada diri mereka sebagai siswa yang belajar matematika akan memberikan peranan penting dalam pembelajaran dan kesuksesan mereka dalam matematika atau bahwa terdapat hubungan yang positif antara selfconfidence dengan hasil belajar matematika. (Hannula, Maijala, \& Pehkonen, 2004)

Menurut Putra, siswa yang memahami konsep matematika akan memiliki rasa percaya diri yang tinggi dalam menyelesaikan masalah.(Putra, 2018) Pengertian matematika yang telah disebutkan di atas memerlukan siswa untuk berpikir rasional, realistis dan objektif yang kesemuanya adalah beberapa indikator dari kepercayaan diri. Siswa yang memahami konsep matematika akan memiliki rasa percaya diri yang tinggi dalam menyelesaikan masalah. Kepercayaan diri akan memperkuat motivasi dalam mencapai keberhasilan belajar, semakin tinggi kepercayaan diri semakin kuat pula semangat dalam menyelesaikan pekerjaan. (Hendriana, 2012)

Kepercayaan, minat dan keyakinan siswa dalam belajar matematika berhubungan langsung dengan guru. Dalam proses pembelajaran ini, guru berperan sebagai motivator dan fasilitator. Mereka bertugas memberi dorongan dan rangsangan dan memahami serta memberi bantuan ketika dibutuhkan. Dorongan dan rangsangan ini dapat diberikan guru dalam bentuk yang menyenangkan dan lebih nyata seperti permainan maupun pembuatan karya seni. Beberapa contoh topik Matematika yang dapat dikaitkan dengan mata pelajaran lain lain simetri, nisbah, dan fraktal dikaitkan dengan pelajaran kesenian serta teori bilangan pada musik. Hal ini sebagai bentuk penjabaran Matematika secara konkret pada kehidupan maupun mata pelajaran lain. Hal ini dapat menghapus kesan bahwa pelajaran Matematika lebih banyak menempatkan siswa sebagai obyek dengan menerima saja teori dan menghafal rumus. Dengan diterjemahkan dalam kehidupan yang nyata, penggunaan simbol yang abstrak itu membuat pelajar mudah memahami Matematika. Kemudahan dalam mempelajari matematika dapat membuat siswa menghargai dan mencintai matematika. Dengan adanya ketertarikan dalam belajar matematika membuat siswa percaya diri bahwa pelajaran sesulit apapun dapat dipelajarinya, sehingga membuat siswa lebih termotivasi dan tertarik untuk belajar dan berprestasi di sekolah.

\section{SIMPULAN DAN SARAN}

Berdasarkan pembahasan dapat disimpulkan bahwa kepercayaan pada diri siswa dalam belajar matematika akan memberikan peranan penting dalam pembelajaran dan kesuksesan mereka dalam matematika atau dapat dikatakan bahwa terdapat hubungan yang positif antara self confidence dengan hasil dalam pembelajaran matematika. 
Desimal, 2 (2), 2019 - 153

Meri Andayani, Zubaidah Amir

Berdasarkan kesimpulan, peneliti menyarankan yaitu agar dapat mengkaji masalah dengan jangkauan yang lebih luas.

\section{DAFTAR PUSTAKA}

Amir, Z. (2015). Mengungkap Seni Bermatematika dalam Pembelajaran. Suska Journal of Mathematics Education, 1(1).

Firdaus, A. R. (2018). Application of Everyone is A Teacher Here Learning Model To Improve Self Confidence Students. PrimaryEdu, 2(2), 87-94.

Hannula, M. ., Maijala, M., \& Pehkonen, E. (2004). Development of Understanding Self-Confidence in Mathematics. In Proceedings of the 28th Conference of the International Group for the Psychology of Mathematics Education.

Hendriana, H. (2012). Pembelajaran Matematika Humanis dengan Metaphorical Thinking untuk Meningkatkan Kepercayaan Diri Siswa. Infinity Journal, 1(1).

Maarif, S. (2015). Integrasi Matematika Dan Islam Dalam Pembelajaran Matematika. Jurnal Ilmiah Program Studi Matematika STKIP Siliwangi Bandung, 4(2).

Martyanti, A. (2016). Keefektifan Pendekatan Problem Solving Dengan Setting Dan TAI Ditinjau Dari Prestasi Dan Self-Confidence. Jurnal Riset Pendidikan Matematika, 3(1), 1-15.

Mostajaboldavati, S. A., Khansanami, F., \& Khansanami, S. (2017). A Comparative Study Of Self Confidence from The Perspective of Quran, Ahadith and Psychology. Health, Spirituality and Medical Ethics, 4(1), 39-44.

Putra, H. . (2018). Kemampuan Pemecahan Masalah Matematis dan Self-Confidence Siswa SMP. SJME (Supremum Journal of Mathematics Education), 2(2).

Ramayulis. (2015). Dasar-Dasar
Kependidikan. Jakarta: Kalam Mulia. Sumarmo, U. (2017). Hard Skill and Soft Skill Matematik Siswa. Bandung: PT. Refika Aditama.

Syam, A., \& Amri. (2017). Pengaruh Kepercayaan Diri (Self Confidence) Berbasis Kaderisasi Imm Terhadap Prestasi Belajar Mahasiswa. Jurnal Biotek, 5(1).

Vandini, I. (2015). Peran Kepercayaan Diri Terhadap Prestasi Belajar Matematika Siswa. Jurnal Formatif, $5(3)$.

Warda, A. K., Mashuri, \& Amidi. (2017). The Effectiveness of SSCS Learning Model with KNWS Strategy towards Mathematical Creative Thinking Ability and Self Confidence of Student. Unnes Journal of Mathematics Education, 6(3), 308-317.

Yusmanto, \& Herman, T. (2015). Pengaruh Penerapan Model Pembelajaran Discovery Learning Terhadap Peningkatan Kemampuan Berpikir Kritis Matematis Dan Self Confidence Siswa Kelas V Sekolah Dasae. EduHumaniora, 7(2), 140-151. 